\section{A Simple Device for Measuring Differences in Hydraulic Head Between Surface Water and Shallow Ground Water}

\section{Introduction}

This fact sheet describes a simple device for measuring the vertical hydraulic gradient (VHG) of shallow ground water beneath a stream bed. The VHG can be used to determine whether a stream is receiving or losing water at the point of measurement. Used as part of a spatial or temporal survey, such measurements can yield valuable information about the local hydrology of a stream/ground-water system. This device also can be used to withdraw shallow subsurface water for chemical analyses. The device is inexpensive and lightweight, but lacks the precision and range of measurement of other probes, such as those described by Winter and others (1988) and Duff and others (1998).

\section{Purpose of Measurements}

Environmental investigations in streams often focus on chemical mass balances to determine the sources, sinks, and biogeochemical processes affecting solute transport along a reach. These calculations rely on whole-stream discharge measurements and fail to describe small-scale chemical and hydrologic interactions between shallow ground water and the stream. The flux of water into or out of the ground is a function of the difference in hydraulic head between surface and subsurface water, so a rapid means of evaluating the head differences aids the hydrologist in determining the possible movement of water into or out of a stream.

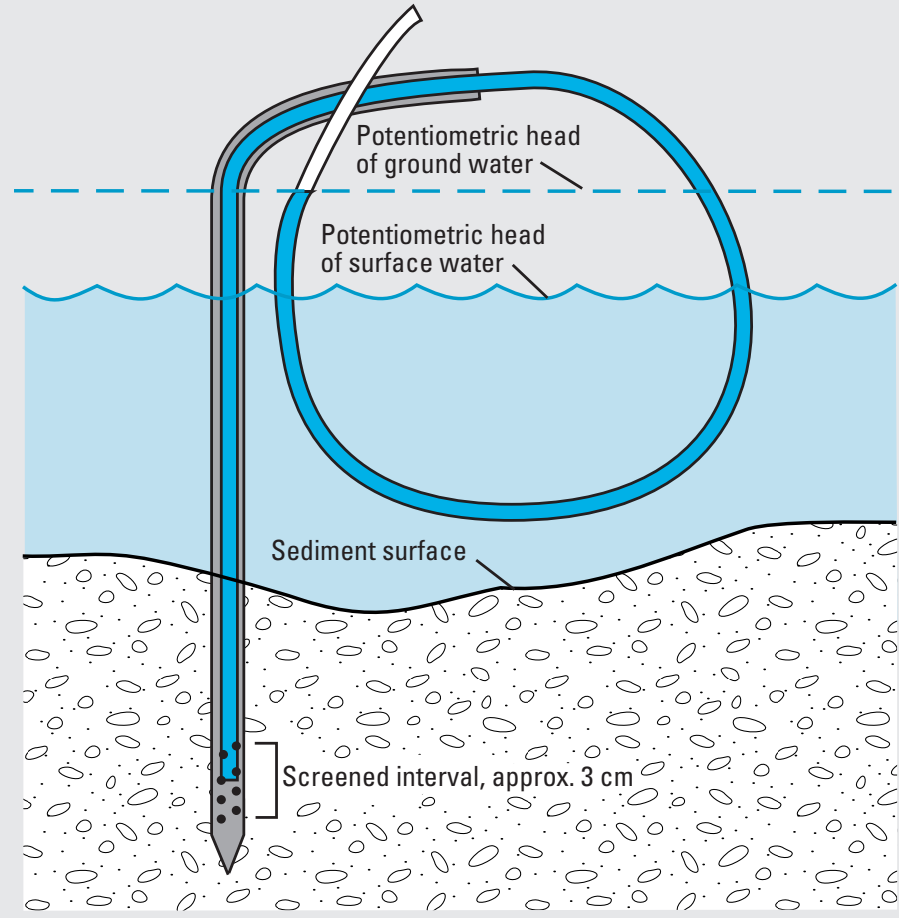

Figure 1. Device for measuring hydraulic head.

\section{Measurement Procedure}

The VHG of substream water can be determined easily using a device such as the one shown in figure 1. The device consists of a cylinder of stiff metal tubing, fashioned with a pointed tip, and having a number of small holes (approx. $3 \mathrm{~mm}$ ) drilled near the bottom along the sides. These devices have been constructed using a commercially available tree-root aerator and 1-meter lengths of square cross-section, cold rolled steel. Other materials, including stainless steel tubing, can be used as well (Duff and others, 1999). The advantage of the materials mentioned above is that they are readily available, inexpensive, and easy to work with. A transparent, flexible plastic tube is inserted into the device to within $1 \mathrm{~cm}$ of the bottom and enough slack is left on the exposed end of the plastic tube to form a large loop. The end of the plastic tube can be held in place with a zip tie or tape. Tape or stainless-steel hose clamps can be fastened to the outside of the device to indicate depth in the sediment to which the device has been inserted. 
The device is inserted into the stream sediment, either by pushing or hammering, to the desired depth (usually 20-40 cm). Subsurface water is drawn into the plastic tube using a $60 \mathrm{~cm}^{3}$ syringe. It may be necessary to "develop the well" by alternately pumping water in and drawing it back out through the plastic tube. If the water is to be analyzed for chemical constituents, only substream water should be reinjected in this process. Once water is readily produced through the device, the syringe is removed and the water level in the open end of the tube is measured relative to the level of stream water. If the bottom of the loop is lower than the hydraulic head of the substream water, the water will not siphon back down through the loop. If the water level in the tube is higher than the stream level, the VHG is positive and the stream is gaining water, as shown in figure 1 . If the water level in the tube is lower than the stream level, the VHG is negative and the stream is losing water. In many cases, no appreciable head difference is discernible, suggesting no flow in either direction, or that there is a hydraulic connection along the cylinder between the stream and the subsurface.

Between measurements, the holes in the bottom of the probe can be cleaned with a pipe cleaner.

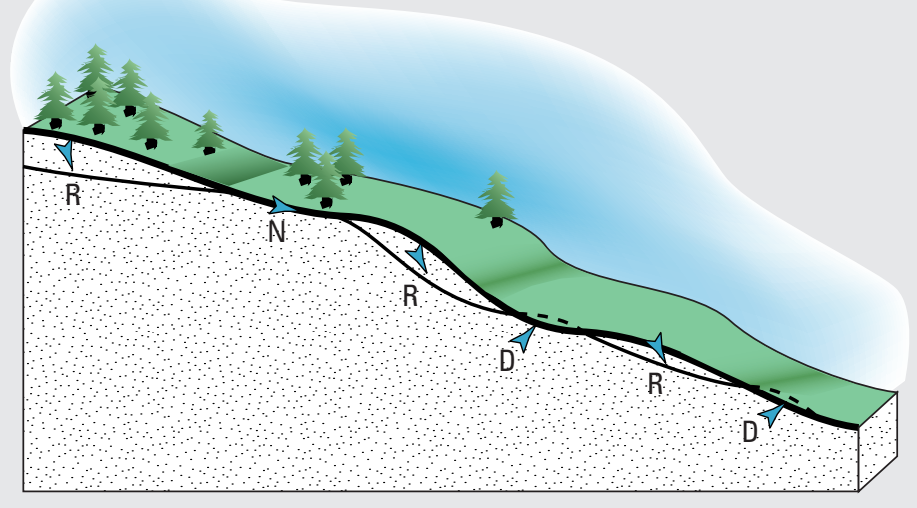

Figure 2. Conceptual landscape.

\section{For more information, contact:}

\section{Richard B. Wanty (rwanty@usgs.gov)}

U.S. Geological Survey

M.S. 973 Denver Federal Center

Denver, CO 80225

Thomas C. Winter (tcwinter@usgs.gov)

U.S. Geological Survey

M.S. 413 Denver Federal Center

Denver, CO 80225

\section{Expected Results}

The conceptual landscape in figure 2 shows a stream reach with several changes in slope. In general, the potentiometric surface of the ground water (shown by the thin black line) is a muted expression of the surface topography. In the areas marked with an "R", surface water should filter into the ground, leading to ground-water recharge. In areas marked with a "D," the opposite is true, and ground-water discharges to the stream. The area marked "N" has neither recharge nor discharge. A survey along this stream reach would reflect these relationships. Winter and others (1998) describe a greater variety of landscapes.

An important aspect of conducting such a hydraulic head survey is to view and understand the results in the context of the landscape, including the topography and vegetation. Geologic variations, including variations in lithology or structure, play a major role in defining ground water-surface water interactions. The detailed measurements that are possible with this device should aid the interpretation of natural systems in the context of geologic and landscape processes.

\section{Recommended Reading}

Duff, J.H., Murphy, F., Fuller, C.C., Triska, F.J., Harvey, J.W., and Jackman, A.P., 1998, A mini drivepoint sampler for measuring porewater solute concentrations in the hyporheic zone of sand-bottom streams: Limnology and Oceanography, v. 43, no. 6, p. 1378-1383.

Duff, J.H., Toner, B., Jackman, A.P., Avanzino, R.J., and Triska, F.J., 1999, Determination of groundwater discharge into a sand and gravel bottom river--A comparison of chloride dilution and seepage meter techniques: Verhandlungen Internationale Vereiningen Limnologie, v. 27, p. 1-6.

Winter, T.C., LaBaugh, J.W., and Rosenberry, D.O., 1988, The design and use of a hydraulic potentiometer for direct measurement of differences in hydraulic head between ground water and surface water: Limnology and Oceanography, v. 33, no. 5, p. 1209-1214.

Winter, T.C., Harvey, J.W., Franke, O.L., and Alley, W.M., 1998, Ground water and surface water--A single resource: U.S. Geological Survey Circular 1139 , p. 79. 